\section{Carnegie Trust for the Universities of Scotland}

THE forty-first annual report of the executive committee of the Carnegie Trust for the Universities of Scotland (Edinburgh : Carnegie Trust for the Universities of Scotland) covers the year 1941-42. The method of interim distribution begun in the academic year 1940-41 was again employed, the annual grants being subjected to a 10 per cent deduction to safeguard the position at the close of hostilities. It has now been arranged that application for grants for research may be made at any time during the year and will be considered by the Executive Committee at such times as may be found convenient. With regard to assistance to students, there was a decrease of 184 beneficiaries in 1941-42 as against 1940-41, the fall being almost wholly among male students, and the decrease was greatest in the faculty of arts; in the faculty of medicine there has been an increase, whereas in the faculty of science the figures have remained relatively steady. The year has been. noticeable for the number of repayments made by Scottish graduates now abroad. Appendixes include a report upon the work of investigators under the research scheme during the academic year 1941-42, in which reference is made to work on the synthesis of methyl-glucoses and related studies, the attempted synthesis of a bis-isoquinoline derivative with a structure related to that of emetine, to work on the chernistry of penicillin, investigations on the eel-worm disease of potatoes, the reliability of mental tests, and to Dr. A. P. Hickie's work under Dr. W. O. Kermack at the Royal College of Physicians' Laboratory, Edinburgh, on the preparation of pyridoquinoline compounds with a constitutional relation to compounds of known anti-malarial activity.

Further reference to this work is made in the report of the superintendent of the laboratory of the Royal College of Physicians for the academic year 1941-42, which is also appended. Research in the Chemical Department under Dr. Kermack's supervision has been mainly in this field of synthetic anti-malarials. The synthesis of new $m$-phenanthrolines has now been taken up by Dr. W. Tebrich, and work on o-phenanthroline derivatives has also been continued and the nitration of 4-chloro-2-methylquinoline has been examined. Good progress has been made in work on the synthesis of derivatives of the complex ring system pyridoacridine, and the preliminary account of Dr. Tebrich's investigations jointly with Dr. J. M. Robson on the penetration of albucid soluble into the ocular tissues of rabbits following local application has already appeared in NATURE (148, 167; 1941). In the Department of Histology, studies of breast cancer have been continued, as well as an intensive study of a remarkable case of generalized sarcoidosis ; and in the Bacteriological Laboratory the search for a basic medium for the cultivation of bacteria has been continued. Lists of publications by fellows, scholars and recipients of grants received since September 30, 1941, and of publications by teaching fellows are also appended to the report, with details of assistance to students and the abstract of accounts for the year ended September 30, 1942.

\section{Sir John Floyer (1649-1734)}

A PAPER on "Sir John Floyer and his Times" was read recently before the Johnson Society by Mrs. Lilian Lindsay, honorary librarian of the British Dental Association. Sir John Floyer was born in 1649 at Lichfield, the birthplace of Samuel Johnson, and was educated at Queen's College, Oxford, where he took his M.B. in 1674 and his M.D. in 1686. The course consisted in readings in the medical classics and memorizing the aphorisms of Hippocrates and the works of Galen. Theses were written and were upheld in disputation. There was no clinical teaching or opportunity for practical experience. The more serious students went abroad for this, especially to Padua. In 1686 Floyer was knighted. In 1687 appeared his first book entitled "The Touchstone of Medicines Discovering the Vertues of Vegetables, Minerals and Animals by their Tastes and Smells", which was published by Dr. Johnson's father, in the preface to which he mentions that he had visited the Garden which the Society of Apothecaries had brought in 1671 and was first called the Physic Garden in. 1678. In 1697 he published an inquiry into "The Right Uses and Abuses of Hot, Cold and Temperate Baths in England", which contained a history of bathing from the earliest times and showed that Floyer had visited all the available springs, wells and watering places in Great Britain.

Floyer's chief contribution to medicine, however, was his work on "The Pulse Watch" (1707), in which he related how for many years he tested healthy pulses among his patients by pendulum clocks and common watches until he found a minute glass which he used in his experiments on cold bathing. His "Treatise on Asthma", of which the first edition was published in 1698 and the third in 1745, gave the first description of pulmonary emphysema in asthma, from which he suffered himself. In 1725 appeared his "Medicina Gerocomica, or Galenic Art of Preserving Old Men's Health", in which he advocated fresh air, exercise, regular diet and temperance in all things, especially alcohol and tobacco. Two of his contributions were read before the Royal Society, one on the dissection of a monstrous pig and the other on the sweet taste of plants. In conclusion, Mrs. Lindsay remarked that Floyer resembled John Hunter in his passion for experiment but lacked his genius in interpretation and orderly thinking.

\section{Earthquakes Registered in New Zealand}

DURING January 1943 only four distant earthquakes were registered by the seismographs at Auckland, Arapuni, Christchurch and Wellington, New Zealand, according to the provisional bulletin just received (Provisional Bulletin No. P-131, New Zealand Seis. Rep., Dominion Observatory, Wellington, N.Z., Jan. 1943). The first earthquake was on January 2. $P$ waves were received at Auckland at 19h. $32 \mathrm{~m}$. 20s. U.T. from an epicentre $22^{\circ}$ distant. The second, on January 9, came from an epicentre some $25^{\circ}$ from Wellington, $P$ waves arriving at this place at $02 \mathrm{~h} .20 \mathrm{~m}$. 01s. U.T. The third shock was on January 27, possible $P$ waves arriving at Wellington at $02 \mathrm{~h}$. $58 \mathrm{~m}$. 30s. U.T. from an epicentre $95^{\circ}$ distant, though interpretation of this record was difficult owing to the small amplitudes being confused by microseisms. The last shock of the month, the epicentre of which was at a greater distance than $10^{\circ}$ from Wellington, occurred on January 30 . $P$ waves were received at Christchurch at $06 \mathrm{~h}$. $05 \mathrm{~m}$. 40s. U.T. from an epicentre some $53 \mathrm{~km}$. distant. During the month there were in addition twenty-five earthquakes the epicentres of which were at a distance less than $10^{\circ}$ from Wellington. All but four of these were felt at some place or other in New Zealand; two were felt at Wellington, three at Masterton, and 